\title{
THE FORMS AND TERMINOLOGY OF THE SIREH TRADITIONAL DANCE'S MOTION IN NORTH LOMBOK REGENCY
}

\begin{abstract}
This research aims to identify and describe motion and its terminology in the Sireh Dance at the Sireh Briuk Sadar Art Studio, Buani, Bentek Village, North Lombok Regency. The qualitative approach was used to collect data through observation, interviews, and documentation. The obtained data were analyzed by reducing, grouping, and summarizing all information. The results showed that the Sireh dance motions consisted of filler, stationary, and moving motion with the upper and lower limbs arranged into four stages called the Tumpang Tampik, Gending Alus, Kjerot, and parade.
\end{abstract}

Keywords: Motion, Terminology, Traditional Dance

\section{INTRODUCTION}

The sireh dance is a popular traditional dance in the North Lombok Regency, were female dancers are dressed in male costumes ((Wirawan, 2019) dan (Harmin, 2017). It is a composition of filler, moving and stationary motion, divided into several groups or stages. Generally, it comprises a range of motions, namely a) Tumpang tampik, b) Gending alus, c) Kjerot, and d) Parade. The use of certain terms or terminologies derived from the several motions and tempo of the music distinguishes it from other dances.

Motion and Terminology according to (Hadi, 2007) stated that "Dance motion is a language derived from the dancer's movements." It is also defined as a form of pose created by the several motions of the dancer's body parts (Putri et al., 2015) and it is in accordance with (Oktariani \& Istiandini, 2015) and (Kristiana, 2015).

Terminology is a marked term with characteristics that do not exist in units not closely related (Kridalaksana, 2008). Some regions have included studies to facilitate trainers and learners in their traditional dance, such as the Javanese classical (Brakel-Papenhuyzen, 1991). Furthermore, terminology also functions as a reference to related dance studies on its preservation and development. 


\section{METHODS}

This study applied a textual and qualitative approach, where objects are perceived from a physical perspective. It was carried out by the choreographical analysis of the various forms, techniques, and styles. (Hadi, 2007)and(Shek et al., 2017:217).This research is based on the Form and Terminology of the Sireh Dance Motion at the Sireh Briuk Sadar Art Studio, Buani, Bentek Village, North Lombok Regency. The data collection techniques were observation, interviews, and documentation. The data were further analyzed in accordance with Miles and Huberman's research, which comprises of reduction, presentation, and conclusions or verification (Sugiono, 2016).

\section{RESULT}

\section{General Description of Sireh Dance}

This dance originated from the North Lombok and has been preserved by the Sireh Briuk Sadar Art Studio, Buani, Bentek Village, which focuses on activities that involve the preservation of the art. This studio was established in the 1970s, and to date, it maintains the original form of the dance.

Based on the results from this study, the Sireh dance was originated when some women consumed areca nut/jol in large quantities and became drunk. Itu caused them to become unconscious, and they started dancing with cloth/Kereng and Udeng (the headbands of men from the Sasak tribe). It became a popular traditional dance with an unknown originator. It is a group dance that usually involves an even number of dancers. Male costumes such as the Udeng (headband) and Kereng (cloth) are used and are as shown in figure 2 .

Five types of musical instruments are used, namely a) Kidur, b) Traditional Flute, two Kendang, d) Rincik, and e) Kajar/Petuk, as shown in the following figure 1. In addition, different rhymes in accordance with the flute melody are sung by all dancers while dancing, and their motions complement the use of these instruments. The rhyme is 
stated as follows.

"dua tiga jarumku patah

Jangan simpan di dalam peti

Kalau ada kataku salah

Jangan simpan di dalam hati"

“iji ijo siq daun biloq

ijo ijo siq daun biloq

gilir sik pacing tuna

ito ito kon diki tindok

derak pikir jari terune"

"olah-olah sik daun paku

Olah-olah sik daun paku

Buak bila sik bawak bengkel

Mun sekolah sik pacu-pacu

Ager erak dek pade nyesel"

"melengku ne bak lokoq beleq

Mbe jalan baq murnangga

Melengku ne jeremeq-remeq

Arak cemburu pacar pertama"

"lampak-lampak tipak gangga

Nendek lupak dengan luek

Lamun bajang jaman nengka

Ndek demen beraye sekeq"

The Sireh dance floor pattern comprises of four parts as follows:

1. The dancers are arranged in two rows, facing the same direction.

2. Square pattern, facing each other.

3. They are arranged in two rows, facing each other.

4. One-shaf pattern, and simultaneously face forward.

All explained as shown in the following figure 3 up to 6

\section{Forms of Motion}

Sireh dance consists of several forms of motion, which are grouped into sedentary and motions. Furthermore, it has one form of filler motion that is always indulged in the various ranges of movements.(Li et al., 2002) and (Shiratori et al., 2004). It is performed by opening and closing the palm accompanied by moving the hand up and down with two forms of leg poses. In the first pose, the right leg is placed behind the left one in a bent 
position.(Metan, 2019); (Subari, 2017) and (Muhimmah, 2019) Subsequently, in the second pose, the right leg is placed in front of the left one at a distance of approximately $20 \mathrm{~cm}$. The tip of the right toe is raised and rests on its heel.(Fajrianti \& Imtihan, 2019); (Fajri et al., 2020); and (Suryo \& C, 2014), The forms of motion in this style of dance are grouped into two, namely:

\section{Sedentary Motion}

Head, shoulder and hand motion. This motion is dominated by the middle and upper limbs, from the hips to the head and it consists of:

1. Head motion is performed by turning the head left and right following the rhythm of the music. This explained as shown in the following figure 7 and 8 .

2. Shoulder motion (Kjerot) is performed by alternatively rotating the left and right shoulders backward and is following Kidur's blow.

3. Hand motion

a. This involves bending and flexing the fingers accompanied by turning the palm simultaneously. This explained as shown in the following figure 9 and 10.

b. Tumpang tampik is performed by positioning the hands in front of the body at a distance of approximately $25 \mathrm{~cm}$. The two palms are placed in opposite directions during the dance, the right one faces upward while the left-hand faces downward. The right-hand needs to align with the thigh when swung down, while the left remains parallel to the chest.

c. Hand motions (wagging Leang)

1) The two hands are simultaneously swung forward and backward with the upper arm in a downward position.

2) Second form consists of different motions of the left hand and right hands. The upper left arm is straightened to the side while the lower arm is bent upward, and the tip of the middle and ring fingers need to touch the left shoulder. The right- 
hand holds the end of the Leang and is swung inward or to the left. The right arm is placed in a downward position while the lower arm is bent toward the abdomen until the wrist is parallel to the hip. During movement, the arms are swung side by side with the palms facing outward, while the wrist is turned towards the ear.

4. Hip motion is performed with hands placed on it while holding the Leang.

The hips are alternatively shaken to the left and right three times, and it is ended by simultaneously wagging the leg to the left.

5. Leg motion consists of two forms, namely.

a. First leg motion.

One foot is used as a support while the other is made to cross it in front. The front end of the foot touches the floor during this motion, in a tiptoe manner, in addition, it is alternated between the left and right legs. When swinging the foot outward, it is given a slight beat.

b. Second leg motion

This is the opposite of the first leg motion, and the part of the foot that touches the floor is the heel.

\section{Moving Motion}

Stepping, Fast Shifting, and Dragging Motion. This motion is dominated by lower limbs or leg motions.

1. Stepping motion is performed by lifting the left leg higher than the right one with a slight beat. This motion is repeated three times and ends by swinging the right leg forward while turning to the body to the left.

2. Fast Shifting Motion (Parade) is performed with the foot fully attached to the floor, and moving sideways with small steps. It starts with the right, followed by the left foot, and the feet need not collide when stepping or shifting to the side. This explained as shown 
in the following figure 11.

3. The second shifting motion is performed by dragging the feet to the side, forming the letters "I I" and "/ /." The direction of the motion is to the right, and whenever this movement is stopped, the left foot is moved forward, etc.

\section{Sireh Dance Terminology}

The terminology of traditional dance is a term or language that suits the history of the dance. In the Sireh dance, not all the basic motions composing the dance have a term. In this context, it refers to the numerous dance rounds, represented by a particular form of basic motion.

In addition, it is also complemented by either fast or slow tempo or atmosphere of the music. The terms involved in the Sireh dance are;

1. Tumpang Tampik is derived from a specific form of motion in the Sireh dance.

2. The next term is referred to as Gending alus based on a slow tempo.

3. The term Kjerot is derived from a certain form of motion, which involves the alternative movement or rotation of the left and right shoulders backward.

4. The beginning of a fast tempo marks parade, and this term is applicable in the four range of motions characterized by the dancers' swift movement to the side. During any performance, this motion is only conducted once, and it is usually at the end.

\section{CONCLUSION}

Based on the results of this research and discussion, the following conclusions were made:

1. The Sireh dance does not involve several basic motions rather it is dominated by a repetition of these motions, which is divided into

a. The sedentary motion which involves the movement of the upper and lower bodies.

1) Head motion,

2) Shoulder motion (Kjerot), 
3) Hand motion (finger motion, Tumpangtampik, wagging Leang)

4) Hip motion,

5) Foot motion (crossed and open foot motions, heels touching the floor).

b. Moving motion consisting of movement of the lower body

1) Stepping motion,

2) Swift shifting motion (Parade), and

3) Shifting motion with the soles of the feet on the floor.

2. The terminologies in this type of dance motions are Tumpang Tampik, Gending Alus, Kjerot, and Parade. It is due to the fact that it relies on the stages of the dance. Terminology is derived from a particular form of motion, as well as the tempo of the music being played. Tumpang Tampik involves the alternative turning of the right and left palm. Gending Alus is derived from the early tempo in the second round of the Sireh dance. Kjerot involves the alternative movement or rotation of the left and right shoulders backward. Meanwhile, parade is the swift movement to the side by lifting the soles of the feet as high as $5 \mathrm{~cm}$.

\section{REFERENCES}

Brakel-Papenhuyzen, C. (1991). Seni Tari Jawa: Tradisi Surakarta den Peristilahannya [Javanese Dance: Surakarta Tradition and Terminology]. Leiden: State University of Leiden.

Fajri, B. R., Samala, A. D., \& ... (2020). Perancangan Media Interaktif Gerak Tari Topeng Patih pada Wayang Topeng Malangan Menggunakan Sensor Kinect. INVOTEK: Jurnal Inovasi .... http://invotek.ppj.unp.ac.id/index.php/invotek/article/view/715

Fajrianti, N. A., \& Imtihan, Y. (2019). Komposisi Gerak pada Pertunjukan Kesenian Tari Petuk di Desa Sade Kabupaten Lombok Tengah. TAMUMATRA: Jurnal Seni Pertunjukkan, 1(1).

Hadi, Y. S. (2007). Kajian Tari: Teks dan Konteks. Pustaka Book Publisher.

Harmin, S. (2017). Morfologi Kultural Dan Nilai Budaya Dalam Gawe Beleq Di Bayan Lombok Utara Serta Relevansinya Terhadap Pembelajaran Muatan. RETORIKA: Jurnal Ilmu Bahasa, 2(2), 364-383.

Kridalaksana, H. (2008). Kamus linguistik edisi keempat. Jakarta: Gramedia Pustaka Utama, 242.

Kristiana, D. (2015). Analisis Struktur Gerak Tari Trayutama. Universitas Negeri Semarang.

Li, Y., Wang, T., \& Shum, H.-Y. (2002). Motion texture: a two-level statistical model for character motion synthesis. Proceedings of the 29th Annual Conference on Computer Graphics and Interactive Techniques, 465-472.

Metan, Y. (2019). Kreativitas Koreografi Dan Enkulturasi Tari Likurai Pada Sanggar Tari Green Sman 4 Kota Kupang. lib.unnes.ac.id. https://lib.unnes.ac.id/35247/

Muhimmah, S. H. (2019). Elemen Dan Makna Gerak Tari Dara Ngindang Di Sanggar Seni Teruna Bebadosan Desa Lenek Kecamatan Lenek, Lombok Timur. TAMUMATRA: Jurnal Seni 
Pertunjukkan, 1(2).

Oktariani, D., \& Istiandini, W. (2015). Analisis Struktur Gerak Tari Jepin Langkah Simpang Di Kota Pontianak Kalimantan Barat. Jurnal Pendidikan Dan Pembelajaran Khatulistiwa, 4(3), 4.

Putri, R. P., Lestari, W., \& Iswidayati, S. (2015). Relevansi gerak tari bedaya suryasumirat sebagai ekspresi simbolik wanita jawa. Catharsis, 4(1), 16.

Shek, S. Z. S., Yousof, R. M. D., \& Dawam, Z. A. M. D. (2017). Tari dalam Teater: Analisis Perbandingan Konsep Koreografi dalam Dua Teater Muzikal Melayu. Jurnal Melayu, 16(2).

Shiratori, T., Nakazawa, A., \& Ikeuchi, K. (2004). Detecting dance motion structure through music analysis. Sixth IEEE International Conference on Automatic Face and Gesture Recognition, 2004. Proceedings., 857-862.

Subari, L. (2017). Perspektif Bentuk pada Struktur Gerak Tari Klana Jabung. TEROB. https://ejournal.stkw-surabaya.ac.id/index.php/jtr/article/view/90

Suryo, D., \& C, E. P. (2014). Seni Tari Rakyat Dolalak Kajian Nilai Budaya Dan Fungsi Pedidikan Pada Masyarakat. Jurnal Sosialita, http://ojs.upy.ac.id/ojs/index.php/pips/article/view/335/252

Wirawan, I. W. A. (2019). Identifikasi Pendidikan Multikultural Dalam Festival Seni Budaya Pada Komunitas Sasak-Islam Dan Bali-Hindu Di Bayan, Kabupaten Lombok Utara. Widyacarya: Jurnal Pendidikan, Agama Dan Budaya, 2(1), 89-100.

Sugiyono. (2016). Memahami Penelitian Kualitatif. Bandung: Alfabeta. 